\title{
EUROPEJSKA PRASA JAKO NARZĘDZIE DYPLOMACJI ROSYJSKIEJ W JEJ WALCE ZE STOLICĄ APOSTOLSKĄ W OKRESIE SEJMU RADOMSKIEGO 1767/1768
}

\section{Sytuacja polityczna w Rzeczypospolitej na przelomie lat 1767 i 1768 w oczach dyplomacji papieskiej}

Od czasu bezkrólewia po śmierci Augusta III Sasa uwagę Stolicy Apostolskiej przykuwał rozwój sytuacji w Rzeczypospolitej, którą caryca Katarzyna II planowo starała się sobie podporządkować. W tym celu nie tylko forsowała kandydaturę Stanisława Poniatowskiego do tronu, lecz wysuwała także postulat równouprawnienia dysydentów i dopuszczenia ich reprezentacji do sejmu. Trudności z realizacją tego projektu ciągnęły się od czasu bezkrólewia kilka lat, aż do 1767 r., kiedy to caryca zdecydowanie zażądała od króla i książąt Czartoryskich jego realizacji.

Spełnienie żądań Petersburga wspieranego przez inne państwa akatolickie oznaczało uszczuplenie prerogatyw Kościoła katolickiego w Rzeczypospolitej, stąd też Stolica Apostolska zdecydowanie występowała przeciwko tym planom nie tylko w Polsce, ale i na arenie międzynarodowej. W 1767 r. papież Klemens XIII dwukrotnie: wiosną i późnym latem, przedsięwziął starania o zmobilizowanie katolickich państw tzw. koncertu południowego do wystąpienia w obronie katolicyzmu i zagrożonej suwerenności Rzeczypospolitej. Jakkolwiek Paryż, Wiedeń i Madryt podzielały jego punkt widzenia, to jednak nie zdecydowały się na czynną ingerencję w sprawy polskie.

Decydujące okazało się tu stanowisko Paryża zniechęconego do spraw polskich, aczkolwiek nie rezygnującego całkowicie (,sekret królewski”) z prób wpływania na rozwój sytuacji w Rzeczypospolitej. Do papieskiej oceny sytuacji bardziej skłaniał się król Hiszpanii Karol III, który ze względu na wdzięczną pamięć po swej zmarłej w 1760 r. żonie Marii Amalii, córce Augusta III Sasa, żywo interesował się sprawami polskimi, lecz przeważyła postawa Paryża i biernie przyglądającego się rozwojowi sytuacji Wiednia.

Od czasu wypłynięcia kwestii dysydenckiej w okresie bezkrólewia stanowisko Rzymu było w tej sprawie jasne i konsekwentne: papież nie zgadzał się na ograniczenie praw Kościoła katolickiego. Zarazem dyplomacja papieska podnosiła jeszcze jedną kwestię, którą wysunął nie Rzym, lecz Petersburg, a mianowicie kwestię suwerenności Rzeczypospolitej. Wysuwając niesłychane jak na owe czasy żądanie zapewnienia reprezentacji dysydentów miejsc w sejmie, caryca Katarzyna II połączyła sprawę obrony prerogatyw Kościoła katolickiego w Polsce ze sprawą suwerenności Rzeczypospolitej. 
Nie darząc zaufaniem ani króla Stanisława Augusta Poniatowskiego, ani miałkiej opozycji, skupionej przede wszystkim na usiłowaniu detronizacji monarchy, Rzym usiłował skłonić państwa katolickie do bardziej zdecydowanej akcji, lecz jego sytuacja była bardzo trudna. Z jednej strony celem, jaki postawił przed sobą „koncert południowy" było dążenie do ograniczenia ekspansji państw akatolickich, a główny teren tej konfrontacji stanowiła Rzeczypospolita. W związku z tym papież Klemens XIII powinien był liczyć na przychylność stolic katolickich. Lecz z drugiej strony rok 1768 to czas nasilenia konfliktu związanego ze sprawą jezuicką, kiedy to monarchie burbońskie nie tylko szantażowały Stolicę Apostolską, chcąc wymusić na niej kasatę zakonu jezuitów, lecz posunęły się także do zbrojnego zajęcia papieskich enklaw na terenie Francji i Italii ${ }^{1}$.

Chociaż więc poglądy Paryża, Madrytu czy Wiednia na rozwój sytuacji w Rzeczypospolitej były zbieżne z poglądami Rzymu, niemniej jednak istniały pomiędzy nimi zadrażnienia wywierające wpływ na wzajemne relacje, a także niechęć Paryża do zdecydowanej ingerencji w Polsce, które to czynniki okazały się przeważające. Jakkolwiek papież Klemens XIII i jego sekretarz stanu, kard. Luigi Maria Torrigiani, doskonale zdawali sobie sprawę z zaistniałej sytuacji, to wraz z jej rozwojem nie rezygnowali ze starań o zyskanie przychylności Wersalu wobec antyrosyjskiej i antykrólewskiej opozycji w kraju.

Od 1760 do lata 1767 r. papieskim nuncjuszem w Rzeczypospolitej był abp Antonio Eugenio Visconti. Ów znakomicie wykształcony, umiejętnie nawiązujący kontakty z ludźmi, sprawny dyplomata pojechał z Warszawy do Wiednia, jednej $\mathrm{z}$ czterech najważniejszych nuncjatur w Europie, nagradzanych kardynalatem u kresu służby dyplomatycznej. Visconti otrzymał kapelusz kardynalski z rąk Klemensa XIV w 1771 r. (in pectore, ogłoszony w 1773 r.), a na konklawe po śmierci Klemensa XIV był jednym z liczących się kandydatów do katedry św. Piotra²

Wiernie realizując na warszawskiej placówce wytyczne napływające z Rzymu, aktywnie starał się przeciwdziałać staraniom ambasady rosyjskiej i jej polskich adherentów. Starał się zmobilizować do działań polski episkopat, sejm, senat, jak również wpływowych magnatów, zabierając głos nie tylko na audiencjach w Zamku Królewskim, lecz także w sejmie, gdzie kładł nacisk na zasadę wyboru katolika na tron polski oraz przestrzeganie praw obowiązujących w Rzeczypospolitej, w tym zwłaszcza odnoszących się do katolików, drukował też swoje mowy dla nadania im większego rozgłosu³ ${ }^{3}$ Jako wytrawny dyplomata nie miał jednak złudzeń i w swojej

1 W. Kęder, Stolica Apostolska wobec Rzeczypospolitej w okresie konfederacji barskiej 1767-1773, Opole 2006, s. 42-55.

2 D. Squicciarini, Nunzi apostolici a Vienna, Città del Vaticano 1988, s. 178, 182-185;

3 A.E. Visconti, Oratio Illustrissimi, Excellentissimi \& Rdi Domini Antonio Eugenii ex marchioni bus de Vice-Comitibus Archi Episcopi Efesini, SSmi Domini Clementis XIII Papae XIII \& Sedis Apostolicae Nuntii habita in Generalibus Comitiis III. Non. Septembris A. MDCCLXIV, [b.m.] 1764; Antonii Eugenii Vicecomitiis Archiepiscopi Ephesisi Sanctae Apostolicae Sedis Legati ad Serenissimum et Potentissimum Poloniae Regem Stanislaum 
finalnej relacji przesłanej przed opuszczeniem Warszawy do Rzymu zawarł przygnębiający obraz polskich elit zarówno duchownych, jak i świeckich ${ }^{4}$.

Kulminacja konfliktu związanego ze sprawą dysydencką, czyli przeforsowania praw dla dysydentów zgodnie z wolą Katarzyny II, nastąpiła, gdy ambasador carycy, Nikołaj Repnin, w celu złamania opozycji sterroryzował sejm, porywając i wywożąc do Rosji głównych opozycjonistów z biskupem krakowskim, Kajetanem Sołtykiem, na czele. Nie przypadła ona jednak na jego czas jego urzędowania, lecz na początek misji abp. Angelo Marii Duriniego. Sejm radomski (repninowski) odsłonił jądro intryg rosyjskich snutych przez Repnina, polegających na długim zwodzeniu opozycjonistów nadzieją na zmuszenie króla Stanisława Augusta do ustąpienia z tronu. W rzeczywistości Repnin dążył do o przeforsowania przyznania praw dysydentom. Dlatego też abp Visconti, który nie rozwinął jeszcze swojej działalności, gdy caryca rosyjska postawiła sprawę dysydencką na ostrzu noża, nie zdążył narazić się ani królowi, ani rosyjskiemu ambasadorowi. Obowiązek walki o prawa Kościoła katolickiego w najbardziej burzliwym okresie przypadł jego następcy, abp. Angelo Marii Duriniemu, który latem 1767 r. przybył do Warszawy.

\section{Nuncjusz Angelo Maria Durini wobec konfliktu związanego ze sprawą dysydencką}

Gdy nuncjusz Angelo Maria Durni przybył do Warszawy, w stolicy istniały trzy ośrodki polityczne podejmujące decyzje w kwestii dysydenckiej. Pierwszym z nich był Zamek Królewski z królem Stanisławem Augustem i dworem, trafnie określany przez abp. Duriniego mianem ,partito russo-stanislaita”, która to nazwa podkreślała jego zależność od rosyjskiej protektorki króla. Drugi ośrodek stanowiła ambasada rosyjska, gdzie kierujący rosyjską polityką zagraniczną Nikita Panin u schyłku 1763 r. przysłał stojącemu na jej czele, schorowanemu i w podeszłym wieku Hermannowi von Keyserlingkowi młodego i rzutkiego Nikołaja Repnina (obaj byli spokrewnieni). Rosyjscy dyplomaci zgodnie z instrukcjami carycy Katarzyny II wywierali odpowiedni nacisk na króla Stanisława Augusta, mobilizowali własnych stronników oraz obcych dyplomatów: pruskich, angielskich, szwedzkich i duńskich w celu wymuszenia praw dla dysydentów.

Augustum Inclytos Ordines in Regni Comitiis Solemniter Congregatos Oratio habita, Varsaviae Pridie idus Novembris Anno MDCCLXVI; Mowa Jasnie Wielmoznego JMći Xdza Antoniego Eugeniego Visconti Arcybiskupa Efezkiego od S. Stolice Apostolskiey do Nayiasnieyszego Stanisława Augusta Króla Polskiego y do Nayiasn: Rzeczypospolitey Nuncyusza na Seymie Ordynaryinym Warszawskim Roku 1766. Dnia 12. Listopada z Łacińskiey przetlumaczona, Warszawa 1767.

4 Archivio Segreto Vaticano [dalej: ASV], Segreteria di Stato, Polonia 278, f. 236v-255r, Visconti do Torrigianiego, Varsavia 24 IX 1767; T. Chynczewska-Hennel, Elita polityczna Rzeczypospolitej w świetle ,ankiety personalnej” nuncjusza Honorata Viscontiego, w: Władza i prestiz. Magnateria Rzeczypospolitej w XVI-XVIII wieku, red. J. Urwanowicz, Białystok 2003, s. 125-137. 
Trzeci ośrodek stanowiła Nuncjatura Apostolska z przybyłym do Warszawy w lipcu 1767 r. abp. Angelo Marią Durinim5 ${ }^{5}$ Nuncjusz był papieskim przedstawicielem nie tylko wobec Rzeczypospolitej i króla, lecz także wobec Kościoła katolickiego w Polsce, czyli zarówno hierarchii, jak i wiernych. $\mathrm{Z}$ tej racji $\mathrm{w}$ ramach swoich obowiązków kontaktował się nie tylko z władzami Rzeczypospolitej, lecz także z hierarchią kościelną, gdyż biskupi wchodzili też w skład senatu i zajmowali ważne urzędy, oraz z elitami kraju: politycznymi, ekonomicznymi, kulturalnymi.

Należy stwierdzić, że w literaturze przedmiotu przy ocenie działalności dyplomatycznej nuncjusza Duriniego narosło wiele nieporozumień, np. część badaczy zarzucała mu nadmierne zaangażowanie po stronie opozycji antykrólewskiej, brak realizacji wytycznych z Rzymu, stronniczość, niepotrzebne eskalowanie konfliktu z władzami Rzeczypospolitej. Zarzutom tym przeczy analiza materiałów źródłowych. Nuncjusz Durini dokładnie realizował wytyczne napływające z papieskiego Sekretariatu Stanu i dzielnie bronił spraw Stolicy Apostolskiej i polskich katolików. Jego zdecydowane wystąpienia podyktowane były rozwojem sytuacji w kraju, gdy politycznym naciskom Petersburga towarzyszyły gwałty wojsk rosyjskich w Polsce, dewastujących i profanujących kościoły, prześladujących i mordujących katolików.

W związku z tym nuncjusz, by jego słowa dosłyszano, musiał zdecydowanie występować w obronie wiernych. Poniższy fragment $\mathrm{z}$ dzieła A. Kraushara znakomicie obrazuje powyższe problemy: „W wilię otwarcia sejmu zgromadzili się w pałacu Radziwiłłowskim na Krakowskim Przedmieściu wszyscy marszałkowie konfederacyi, celem wspólnej narady nad położeniem sprawy, gdy nadspodziewanie nadjechał przed pałac nuncyusz papiezki i zażądał od Radziwiłła bezzwłocznej audyencyi. Radziwiłł trzymając laskę marszałkowską w ręku, otoczony konsyliarzami, wysłuchał z uszanowaniem francuzkiej, a następnie łacińskiej przemowy dostojnego gościa, w której nawołując zgromadzonych do pieczy około nietykalności wiary, przestrzegł ich, by na sejmie zachowywali się czujnie i baczyli, by religia przy ich współudziale szwanku najlżejszego nie doznała. Wręczył przy tem Radziwiłłowi brewe Klemensa XIII, do stanu rycerskiego wystosowane, a odwodzące szlachtę od powolności żądaniom dyplomacyi w sprawach dyssydentów i przypominającej jej zasługi i missję Polski około krzewienia i pielęgnowania zasad Kościoła i katolicyzmu. Przemowa ta wywarła piorunujące wrażenie na obecnych. Zapomniawszy o wszystkim, co się dotychczas stało, z głośnym okrzykiem: Non recedemus a fide! oświadczyli gotowość swoją poświęcenia życia i mienia w obronie wiary i prosili nuncyusza o błogosławieństwo. Durini uczyniwszy nad zgromadzeniem znak krzyża bezzwłocznie odjechał i skierował się do prymasa, któremu również oddał brewe papiezkie do senatu pisane, wreszcie pojechał do króla, i zażądawszy posłuchania, oddał mu brewe papiezkie w jego własnym gabinecie".

5 Acta Nuntiaturae Polonae, t. 1, ed. H.W. Wojtyska, Romae 1990.

6 A. Kraushar, Ksiaże Repnin i Polska. W pierwszym czteroleciu panowania Stanisława Augusta (1764-1768), t. 2, Warszawa 1900, s. 18-19. 
„Oczywiście jak to w Polsce bywa, natychmiast znaleźli się donosiciele, którzy o wszystkim poinformowali Repnina. Carski ambasador w te pędy przybiegł do zgromadzenia, aby je spacyfikować i zgromadzonym dygnitarzom obiecawszy że ich postulaty będą spełnione dodał, «Przyjechałem tu tylko z wizytą do księcia Radziwiłła, a nie dla traktowania $\mathrm{z}$ wami, gdyż takiego zaszczytu nikt $\mathrm{z}$ was dostąpić nie może, dopóki nie będzie miał pełnomocnictwa od Rzplitej. Od siebie jedynie w zaufaniu powiadam wam, że dziwię się i ubolewam, widząc was w takiem rozdrażnieniu. Zapomnieliście, ile macie dowodów życzliwości ku wam Jej Imperatorskiej Mości, zapomnieliście, że tylko pod jej opieką mogliście się skonfederować dla ocalenia waszej wolności i praw». Mowę Repnina przerwały okrzyki: «Skonfederowaliśmy się także dla obrony wiary katolickiej!». «Przestańcie krzyczeć», zawołał ponownie Repnin, «bo i ja krzyczeć zacznę! Nikt wam nie broni troszczyć się o waszą wiarę: jest to żarliwość chwalebna, lecz któż tu nastaje na katolicyzm? Jeśli chcecie być wierni swojej religii, winniście pełnić wszystkie jej sprawiedliwe przykazania i nie gwałcić przekonań innych. Jeśli chcecie żyć w dobrym sąsiedztwie z Rosyą i korzystać z opieki Jej Imperatorskiej Mości, to dotrzymujcie umów»"ᄁ.

Rozgrywka toczona wokół sprawy dysydenckiej wkroczyła w decydującą fazę u schyłku 1767 r., gdy Repnin na sejmie radomskim zaczął przeć do jej finalizacji, a bieg wydarzeń wskazywał na jej bliskie rozstrzygnięcie. Świadoma tego była też Stolica Apostolska, w Rzymie bowiem w drugiej połowie 1767 r. nad sprawami polskimi obradował tajny konsystorz kardynalski. U schyłku roku, trafnie przewidując rozwój sytuacji, a zarazem będąc świadomym faktu, że wyczerpał możliwości dyplomatyczne, papież Klemens XIII w okresie Bożego Narodzenia w bazylikach patriarchalnych w Rzymie zarządził cykl uroczystych nabożeństw w intencji Polski połączonych z procesjami, w których brał też udział kler, zgromadzenia zakonne i kardynałowie ${ }^{8}$.

Bardzo dobrze zorientowany w sprawie nuncjusz Durini również zdecydował się na przeciwdziałanie poczynaniom Repnina. Niejako prologiem do rozstrzygającego starcia była podróż do Rzymu w charakterze nieformalnego wysłannika antykrólewskiej opozycji Karola Litawora Chreptowicza, marszałka konfederacji grodzieńskiej i posła na sejm radomski, który ogłosiwszy w kraju bardzo głośny manifest przeciwko gwałtom Repnina, przezornie zrejterował za granicę. Dzięki listom polecającym nuncjusza Chreptowicz został w Rzymie bardzo dobrze przyjęty przez czynniki oficjalne na audiencji u papieża Klemensa XIII, u kardynała Torrigianiego, któremu wręczył swój memoriał, oraz przez rzymską socjetę?

7 A. Kraushar, Książę Repnin i Polska ..., t. 2, dz. cyt., s. 20-21.

8 „Gazette d France” Du Vendredi 22 Janvier 1768, s. 26-27, De Rome, le 30 Décembre 1767; W. Kęder, Stolica Apostolska wobec Rzeczypospolitej..., dz. cyt., s. 215-216.

9 W. Kęder, Rzymska misja Karola Litawora Chreptowicza - przyczynek do dziejów dyplomacji konfederackiej na przełomie 1767/1768 roku, w: Od Kijowa do Rzymu. Z dziejów stosunków Rzeczypospolitej ze Stolica Apostolska i Ukrainą, red. M.R. Drozdowski, W. Walczak, K. Wiszowata-Walczak, Białystok 2012, s. 573-585; W. Kęder, Stolica Apostolska wobec Rzeczypospolitej..., dz. cyt., s. 217-219. 
Rzymska eskapada Chreptowicza wzbudziła wściekłość Repnina który nie tylko odgrażał się posłowi, ale też nuncjuszowi Duriniemu, którego oskarżał o współudział w tym ,antyrosyjskim spisku"10. Zarazem odbiła się zaskakująco dużym echem na salonach Europy, i to nie tylko w korespondencji dyplomatycznej, lecz także w gazetach, gdzie poświęcono jej wiele miejsca ${ }^{11}$.

Kulminacja sporu wokół kwestii dysydenckiej nastąpiła w końcu stycznia 1768 r. Otóż Repnin rozważał z Paninem różne warianty represji: od możliwości ograniczenia uprawnień jurysdykcyjnych nuncjatury do jej likwidacji. Wówczas nuncjusz Durini, ostrzeżony o rosyjskim zamiarze uderzenia w Nuncjaturę Apostolską, zdecydował się na iście pokerowe zagranie. Durini w porozumieniu z Rzymem zdobył się na niezwykle ostry publiczny protest $\mathrm{w}$ tej sprawie, mając nadzieję na zmobilizowanie katolickiej opinii publicznej.

Jakkolwiek zdecydowanie niechętny Rzymowi Władysław Konopczyński w swojej monumentalnej Konfederacji barskiej potraktował protest nuncjusza z pewną ironią, to fakty każą na to wydarzenie spojrzeć inaczej. „Bo oto nuncjusz apostolski, Angelo Durini, zaprotestował 30 stycznia «przeciwko wszystkim działaniom, czynom w tem mieście Warszawie, a osobliwie spisanym [...] nieważnym umowom [...] lub traktatom». On dzieła Delegacji [wysłanej przez Repnina do carycy Katarzyny II] za «niegodziwe, bezbożne, występne, nieważne, i nic nie oznaczające, jako od nie mających władzy i mocy lekkomyslnie ustanowione» [...], ogłasza i każdego z wiernych Chrystusowych pod sumieniem obowiązuje, aby ich nie zachowywali, owszem wykonania ich zakazuje i to ostatecznie ogłasza"12.

\section{Rosyjska kontrakcja i inspirowana przez Petersburg ofensywa prasowa}

Zgodna z otrzymanymi z Rzymu wskazówkami nieprzejednana postawa nuncjusza Duriniego wyprowadziła rosyjskich dyplomatów z równowagi. Poinformowany o jego proteście Panin pisał do Repnina: „Co się tyczy gromu watykańskiego, który może zniweczyć cały gmach naszej, na korzyść dyssydentów podjętej roboty, to zalecam wam użycie pieniędzy, gróźb i wszelkich środków, aby doprowadzić króla i magnatów do jednomyślnego uznania grożącego niebezpieczeństwa, a jeśli ono istotnie zajdzie, trzeba ogłosić nuncyusza jako sprawcę niepokoju i intryganta, przytrzymać go przemocą w jego pałacu, tak, by nikt do niego przystępu nie miał, lub, co

${ }_{10}$ Nuncjusz Angelo Maria Durini do kardynała sekretarza stanu Luigi Marii Torrigianiego, Varsaviae 10 II 1768. Acta Nuntiaturae Polonae, t. 52, Angelus Maria Durini (17671772), vol. 1, 12 IV 1766 - 20 IV 1768, ed. A. Kęder, Cracoviae 2016, s. 328.

11 „Gazeta Lejedejska” [dalej: G.L.] („Nouvelles Extraordinaires de Divers Endroits”), N. [Numero] XV, du Vendredi 19. Février, 1768. Supl. [Supplement aux Nouvelles Extraordinaires de Divers Endroits] du Numero 15, [s. 3], Des Bords de la Vistule, le 4. Février. “; G.L., N. XVI, du Mardi, le 23. Février, 1768. Supl. [s. 1-2]; Gazette de Cologne, Du Vendredi 15 Avril 1768, De frontiere de la Pologne le 28 Mart; Nouvelles Extraordinaires de Divers Endroits, Du Mardi 26. Janvier 1768, De Rome, la 30. Décembre.

12 W. Konopczyński, Konfedracja barska, t. 1, Kraków 1936, s. 20. 
najlepsza, wyprowadzić go z kraju pod dobrą eskortą i tak długo ciągnąć tę podróż, aż sejm wszystko zatwierdzi" ${ }^{13}$.

Jak pisał o rosyjskiej reakcji Władysław Konopczyński: „ambasador sam wymierzy sprawiedliwość, nuncjusza jako gwałciciela polskiej niepodległości, wichrzyciela i oszczercę osadzi w domowym areszcie albo na czas do końca Sejmu pod eskortą odstawi do granic, a z nieocenionym Podoskim [prymasem] ukartuje nową ustawę - o przeniesieniu na prymasa i synod narodowy jurysdykcji nuncjuszowskiej" ${ }^{\prime 14}$. Ale ów przewijający się od dłuższego czasu na salonach warszawskich pomysł nie był jedyny. O drugim tak pisze Konopczyński: „Istrieblenije papskoj własti - ustanowienie na jej ruinach nowej niezależnej hierarchii, oczyszczenie Polski z zarazy katolicyzmu - oto cel wspaniały, to wierch sławy, jaki przed oczy stawiał minister [Panin] ambasadorowi [Nikołajowi Repninowi] ${ }^{15}$.

A zatem zirytowany nieprzejednaną postawą nuncjusza Duriniego Panin, dążąc za wszelką cenę do przeforsowania sprawy dysydenckiej zgodnie z rozkazami carycy, wrócił do wcześniej rozważanych pomysłów ograniczenia uprawnień jurysdykcyjnych nuncjatury, albo też bardziej dalekosiężnego planu zerwania zależności polskiego Kościoła katolickiego od Rzymu, którego orędownikiem był prymas Gabriel Podoski. Przez luty trwały prowadzone pod egidą ambasadora Repnina prace nad ograniczeniem uprawnień jurysdykcyjnych nuncjatury. Nie były one tajemnicą i wiedzieli o nich zarówno nuncjusz, jak i kardynał sekretarz stanu, a także opinia publiczna w Polsce i za granicą, gdyż szeroko rozpisywały się o niej gazety europejskie. Posiadający informacje z różnych źródeł kard. Torrigiani przestrzegał nuncjusza Duriniego o tym, że Repnin ze swoimi stronnikami szykuje ostrą rezolucję wymierzoną przeciwko nuncjuszowi ${ }^{16}$.

Tymczasem w ostatnim tygodniu obrad sejmu sprawy przybrały zaskakujący przebieg. Oto bowiem po uchwaleniu 20 lutego żądanych przez carycę Katarzynę II ustaw w sprawie innowierców, 27 lutego, na ostatniej sesji sejmu, ambasador Repnin, odebrawszy przywiezioną przez specjalnego kuriera korespondencję z Petersburga, w imieniu carycy oświadczył, że projekt znoszący uprawnienia jurysdykcyjne nuncjatury został unieważniony i ostentacyjnie podarł go w obecności posłów.

13 W. Kęder, Stolica Apostolska wobec Rzeczypospolitej..., dz. cyt., s. 273-274.

14 W. Konopczyński, Konfedracja barska, t. 1, dz. cyt., s. 21.

15 W. Konopczyński, Konfedracja barska, t. 1, dz. cyt., s. 21.

16 Kardynał sekretarz stanu Luigi Marii Torrigiani do nuncjusza Angelo Marii Duriniego, Romae 14 XI 1767. Acta Nuntiaturae Polonae, t. 52, Angelus Maria Durini..., dz. cyt., s. 237-238; Kardynał sekretarz stanu Luigi Maria Torrigiani do nuncjusza we Francji, arcybiskupa Bernardino Girauda, Roma 4 II 1768. ASV, Segreteria di Stato, Francia 455A, f. 88r-89r; Torrigiani do nuncjusza w Wiedniu, arcybiskupa Antonio Eufenio Viscontiego, Roma 6 II 1768. ASV, Archivio della Nunziatura Apostolica in Vienna, 87, f. 44r; Nuncjusz w Kolonii, arcybiskup Tommaso Maria Ghilini, do Torrigianiego, Colonia 4 II 1768. ASV, Archivio della Nunziatura Apostolica in Colonia, 167, f. 57r-57v; Torrigiani do Duriniego, Roma 20 II 1768. ASV, Segreteria di Stato, Polonia 238, f. 196v-197r. 
W uzasadnieniu swojej zaskakującej decyzji caryca stwierdziła, że projekt ten wzburzył opinię publiczną. Oczywiście był to tylko pretekst, gdyż Katarzyna II niejednokrotnie dowiodła, że w ogóle nie liczy się z polską opinią publiczną.

Jego wystąpienie, w którym poinformował posłów o decyzji carycy, nie poprzedziły żadne informacje, które dawałyby podstawę do przypuszczeń, że w Petersburgu przez dłuższy czas dojrzewała decyzja wycofania się z tej sprawy. Dotychczasowy przebieg sejmu wskazywał na to, że podobnie jak uchwalone 20 lutego prawa dla dysydentów, tak i do końca sejmu uchwalone zostaną prawa wymierzone przeciwko Nuncjaturze Apostolskiej ${ }^{17}$.

Na pytanie zatem, jakie motywy przyświecały rosyjskiej imperatorowej, interesujące światło rzuca kwestia afery dotyczącej nuncjatury warszawskiej, jaka przetoczyła się w tym czasie, a dokładnie w marcu i kwietniu 1768 r. w prasie europejskiej. Oto bowiem wpierw w marcu w „Gazecie Kolońskiej”, a następnie w kwietniu w „Gazette de France” i innych gazetach europejskich ukazały się informacje o rzekomych nadużyciach finansowych w nuncjaturze w czasach arcybiskupa Niccoló Serry (był nuncjuszem w Warszawie w latach 1754-1760), a ściślej jego audytora, Jana Ewangelisty Stefaniniego ${ }^{18}$.

Informacje te w ślad za „Gazetą Kolońską” powieliła prasa francuska i inne gazety europejskie ${ }^{19}$. Nasuwa się tu pytanie, czy informacje te były prawdziwe, czemu

17 Torrigiani do Girauda, 27 II 1768. ASV, Segreteria di Stato, Francia 455A, f. 106v.

18 „Suite de Varsovie, le 2 Mars. On a lù avec surprise dans quelques Feuilles étrangeéres que le Tribunal de la Nunciature, établi en ce Royaume, s'approprioit beaucoup d'amendes p cuniaires, qui quelque-fois montoient à 1000 ducats. Cette nouvelle controuvée, fausse $\&$ calomnieuse ne merire pas le moindre credit, d'autant plus qu'il est très rare que l'on inflige dans ce Tribunal des amen des pécuniaries, qui d'ailleurs n'entrroient ni dans les mains du Nonce ni dans celles de ses Ministres, \& feroient plutôt assignes à des oeuvres pieuses, comme l'ont connu ceux qui y ont connu ceux qui y ont été condamnés. D'apres méme la compulsation des comptes de la Nonciature de cette Ville, on a Eu lieu d'observer, que pedant les 6 Ans du Prelat Serra, le susdit Tribunal n'a infligé que deux amen des pécuniaries, l'une de 100 e l'autre de 30 ducats, \& qui toutes les deux ont été paiées, suivant les ordres du Nonce, a l'Hôpital des Enfans trouvés. Au reste, tout ce qui entre chaque année Au Tribunal de cette Nonciature, tant pour les concessions gracieuses, que pour les affairescontenieuses ne Monte pas a 400 ducats, \& la taxe qu'on y fuir, est la plus modique de toutes Celle qui sont imposees dans tous les autres Tribunaux Ecclésiastiques du Royaume”. „Gazette de Cologne. Avec Privilege de sa Majesté Imperiale” [dalej: Gazette de Cologne] Du Mardi 22 Mars 1768, Supplement.

19 „On a annoncé il y a quelque temps, dans les papiers Public (Voyez la Gazette du 15. Févrie dernier) que le Tribunal de la Nonciature, établi en ce Royaume, s'approproit des Sommer considérables par l'imposition de beaucoup d'amends pécuniaires qui quelquefois montoient à 1000 ducats $\{$ cette assertion est destituée de tous fondement : il e trés rare que l'on ait insi à ce Tribunal desvamendes pécuniaires qui d'ailleurs ne passe nt ni dans les mains du Nonceni dans celles de ses Ministres, \& sont ordiairement appliquées à des oeuvres de charité. On a vérifé que, pendant les six ans de la Nonciature du Prélat Serra, ce Tribunal 
wypłynęły na światło dzienne po tylu latach i czy ich waga uzasadniała zainteresowanie europejskich żurnalistów tym tematem. Pewne światło na ten temat rzuca uwaga, jaką w swoim słynnym pożegnalnym liście, odchodząc z warszawskiej placówki, do kard. de Bernisa rzucił abp Durini: „ekwipaże moje, ani ludzi moich, nie będą obciążone nabytemi w Polsce bogactwy, nie wywiedzie z Polski mój audytor dziesięcin tysięcy czerwonych złotych, jako jego antecesor [G.A. Stefanini] uczynił. Lecz na to miejsce poczciwość jego pójdzie za nim, jako i za inszemi mojemi ludźmi. Co do mnie samego, nie wyprowadzę z sobą ani saskich porcelan, ani sobolów moskiewskich, ani wina starego węgierskiego"20.

A zatem zdaniem Duriniego zarzuty te były słuszne, a nawet sam wymienia ich szczegółowy katalog (pieniądze, porcelana saska, sobole, wina) obciążający audytora Serrę. Czy jednak rzeczywiście były prawdziwe, trudno powiedzieć, nic bowiem nie wiadomo, aby Kuria Rzymska przeprowadziła w tej sprawie jakiekolwiek dochodzenie. Być może do uszu nuncjusza Duriniego dotarły plotki warszawskie na ten temat, lecz plotki nie stanowią dowodów. Sama zaś sprawa łapówkarskich skłonności dworskich i wszelkich innych urzędników, powszechna na europejskich dworach, w tym warszawskim, by wymienić stojącego na czele Gabinetu Królewskiego kanonika Kajetana Ghigiottiego, nie budziła zazwyczaj specjalnych sensacji.

W tym wypadku jednak interesujące są dwie okoliczności. Po pierwsze, czas ukazania się tych informacji ściśle skorelowany z rozstrzygnięciami w sprawie dysydenckiej, jakie zapadały na sejmie warszawskim. Ktoś musiał te informacje przygotować, przesłać je do odbiorców w Holandii, Kolonii i we Francji, a ich opublikowanie zbiegło się z momentem, gdy miały być uchwalone restrykcje skierowane przeciwko nuncjaturze warszawskiej. Po drugie, interesujący jest fakt, że wieści te uderzały bezpośrednio nie w nuncjusza Duriniego, sprawcę całego zamieszania w kraju, lecz w podwładnego nuncjusza Serry, czyli w audytora Stefaniniego, a zatem szkodziły wizerunkowi nie nuncjusza, lecz całej nuncjatury. Gdyby ambasada rosyjska w Warszawie chciała zaszkodzić abp. Duriniemu, rzucając fałszywe oskarżenia, to jak pokazała jej inwencja $\mathrm{w}$ fabrykowaniu oskarżeń przeciwko niewygodnym przeciwnikom po słynnym zamachu konfederatów barskich na Stanisława Augusta, nie miałaby z tym żadnych problemów.

Wynika z tego jeden wniosek: mianowicie Petersburg, dążąc do neutralizacji papieskich dyplomatów, urabiał grunt europejskiej opinii publicznej, przygotowując ją na realizacje jednego z dwóch wariantów: zniesienia jurysdykcji nuncjuszów bądź nuncjatury papieskiej w Warszawie. W rzeczywistości zrealizowano trzeci wariant i caryca

n'a insigné que deux amendes pécuniaires, l'une de 100 \& l'autre de 30 ducats, qui toutes les deux ont été remises, par ordre du Nonce, a l'Hôpital des Enfans Trouvés”. „Gazette de France" Du Vendredi 1. Avril 1768, s. 105, De Warsovie, le 9 Mars 1768.

${ }^{20}$ List A.M. Duriniego do kard. de Bernisa, ambasadora francuskiego w Rzymie, Varsavia 30 I 1771, w: D. Caccamo, Il nunzio A. M. Durini (1767-1772) e la prima spartizione della Polonia, w: Italia, Venezia e Polonia tra illuminismo e romanticismo, a cura di V. Branca, Firenze 1973, s. 59. 
Katarzyna II, przeforsowawszy sprawę dysydencką, wycofała się z akcji wymierzonej w nuncjaturę, nie chcąc podgrzewać i tak gorącej atmosfery w kraju. Czyli nuncjusz Durini swoim pokerowym zagraniem przynajmniej na tym polu odniósł sukces.

Nadspodziewanie przekazane w prasie z kilkuletnim opóźnieniem informacje na temat pechowego audytora nuncjusza Serry spowodowały ogromne zamieszanie. $\mathrm{O}$ enuncjacjach prasowych, jakie w sprawie nuncjatury ukazały się w gazetach niemieckich, holenderskich i francuskich, papiescy dyplomaci informowali na bieżąco Rzym, a wieści na ten temat mocno wzburzyły kard. Torrigianiego. Stolicę Apostolską obszernie informował o tym, przesyłając odpowiednie numery gazet nuncjusz papieski w Kolonii Giovanni Battista Caprara Montecuccoli i podobnie postąpili inni papiescy przedstawiciele na dworach europejskich. Bardzo nerwowo zareagował też na całą sytuację kard. Torrigiani, który uważał powielane informacje za nie odpowiadające prawdzie. Z kolei w swojej korespondencji przesłanej do Rzymu nuncjusz we Francji, abp Bernardino Giraud, informował kardynała sekretarza stanu, że o aferze tej rozmawiał z nim kierujący polityką zagraniczną Francji książę Étienne-François de Choiseul.

Nuncjusz informował też kard. Torrigianiego o tym, że o całej sprawie rozmawiał również z bawiącym w tym czasie w stolicy Francji księciem Sułkowskim, który cytując otrzymywane z Polski listy, wskazywał nuncjuszowi prawdziwe jego zdaniem przyczyny tego ataku na nuncjaturę warszawską. Uważał, że chodzi o forsowaną przez Katarzynę II na sejmie sprawę przyznania praw dysydentom, jak również dyskutowaną w tym czasie kwestię zniesienia trybunału nuncjatury ${ }^{21}$.

W tym wypadku książę Sułkowski trafił w sedno, gdyż trudno jest wyobrazić sobie ministra spraw zagranicznych Francji zajmującego się finansowymi poczynaniami audytora nuncjatury warszawskiej. $Z$ całą pewnością ministrowi Choiseulowi brakowało całego kontekstu tej sprawy, to znaczy potraktowania tej afery jako pretekstu do ataku na nuncjaturę warszawską i osłabienie wpływu Stolicy Apostolskiej na bieg spraw w Rzeczypospolitej.

Kard. Torrigiani bardzo poważnie traktował oskarżenia kierowane pod adresem nuncjatury warszawskiej. Jakkolwiek a priori odrzucał oskarżenia formułowane pod adresem audytora Stefaniniego, to prawdziwych powodów tych ataków dopatrywał się w kwestiach politycznych rozstrzygających się wówczas w Polsce. Inspiratorów tych akcji doszukiwał się natomiast w działaniach rosyjskiego posła w Paryżu, księcia Golicyna, podejrzewając go o inspirowanie prasy do ataków na nuncjaturę warszawską. Jego zdaniem w aferę zamieszane były także gazety niechętne Stolicy Apostolskiej, w tym przede wszystkim ukazujące się w krajach protestanckich ${ }^{22}$.

${ }^{21}$ Giraud do Torrigianiego, Parigi 21 III 1768. ASV, Segreteria di Stato, Francia 531, f. 83r-83v.; Giraud do Torrigianiego, Parigi 28 III 1768. ASV, Segreteria di Stato, Francia 531, f. 89r-89v.; Giraud do Torrigianiego, Parigi 28 III 1768. ASV, Segreteria di Stato, Francia 531, f. 89v-95r.; Giraud do Torrigianiego, Parigi 4 IV 1768. ASV, Segreteria di Stato, Francia 531, f. 105r.

22 W. Kęder, Stolica Apostolska wobec Rzeczypospolitej..., dz. cyt., s. 225-232. 
Cała sprawa związana $\mathrm{z}$ akcją prasową skierowaną przeciwko nuncjaturze warszawskiej tak jak nagle się zaczęła w marcu 1768 r., tak po kilku tygodniach równie raptownie ucichła. Trudno tu oprzeć się wrażeniu, że o jej szybkim zakończeniu zadecydował rozwój sytuacji na sejmie w Warszawie. Caryca Katarzyna II, przeforsowawszy przyznanie praw dla dysydentów, wycofała się w ostatnim momencie z akcji przeciwko nuncjaturze papieskiej w Warszawie, nie chcąc bardziej zaogniać sytuacji, gdyż opinia publiczna i tak całą aferą związaną z innowiercami była mocno wzburzona. Kurier z Petersburga z dyspozycjami carycy przybył do Warszawy w ostatnim momencie, lecz widać było, że Rosjanom zabrakło czasu na to, by w Europie Zachodniej odkręcić całą aferę. W rezultacie przygotowane materiały dotyczące nieprawidłowości w tej placówce ukazały się w prasie europejskiej w tym czasie, w jakim miały się według wcześniejszych planów ukazać, lecz rozwój sytuacji w Warszawie zadecydował o tym, że dalszego ciągu już nie było.

\section{Bibliografia}

\section{Źródła drukowane}

Acta Nuntiaturae Polonae, t. 1, ed. H.W. Wojtyska, Romae 1990.

Acta Nuntiaturae Polonae, t. 52, Angelus Maria Durini (1767-1772), vol. 1, 12 IV 1766 - 20 IV 1768, ed. A. Kęder, Cracoviae 2016.

Visconti A.E., Antonii Eugenii Vicecomitiis Archiepiscopi Ephesisi Sanctae Apostolicae Sedis Legati ad Serenissimum et Potentissimum Poloniae Regem Stanislaum Augustum Inclytos Ordines in Regni Comitiis Solemniter Congregatos Oratio habita, Varsaviae Pridie idus Novembris Anno MDCCLXVI.

Visconti A.E., Mowa Jasnie Wielmoznego JMći Xdza Antoniego Eugeniego Visconti Arcybiskupa Efezkiego od S. Stolice Apostolskiey do Nayiasnieyszego Stanisława Augusta Króla Polskiego y do Nayiasn: Rzeczypospolitey Nuncyusza na Seymie Ordynaryinym Warszawskim Roku 1766. Dnia 12. Listopada z Lacińskiey przettumaczona, Warszawa 1767.

Visconti A.E., Oratio Illustrissimi, Excellentissimi \& Rdi Domini Antonio Eugenii ex marchioni bus de Vice-Comitibus Archi Episcopi Efesini, SSmi Domini Clementis XIII Papae XIII \& Sedis Apostolicae Nuntii habita in Generalibus Comitiis III. Non. Septembris A. MDCCLXIV, [b.m.] 1764.

\section{Gazety}

„Gazette de Cologne. Avec Privilege de sa Majesté Imperiale” (1768).

„Nouvelles Extraordinaires de Divers Endroits” („Gazette de Leyde”) (1767-1768). 


\section{Źródla rękopiśmienne}

Archivio Segreto Vaticano, Segreteria di Stato, Francia 455.

Archivio Segreto Vaticano, Segreteria di Stato, Francia 531.

Archivio Segreto Vaticano, Archivio della Nunziatura Apostolica in Vienna, 87.

Archivio Segreto Vaticano, Archivio della Nunziatura Apostolica in Colonia, 167.

Archivio Segreto Vaticano, Segreteria di Stato, Polonia 238.

\section{Bibliografia}

Caccamo D., Il nunzio A. M. Durini (1767-1772) e la prima spartizione della Polonia, w: Italia, Venezia e Polonia tra illuminismo e romanticismo, a cura di V. Branca, Firenze 1973, s. 37-68.

Chynczewska-Hennel T., Elita polityczna Rzeczypospolitej w świetle „, ankiety personalnej" nuncjusza Honorata Viscontiego, w: Władza i prestiz. Magnateria Rzeczypospolitej w XVI-XVIII wieku, red. J. Urwanowicz, Białystok 2003.

Kęder W., Rzymska misja Karola Litawora Chreptowicza - przyczynek do dziejów dyplomacji konfederackiej na przetomie 1767/1768 roku, w: Od Kijowa do Rzymu. Z dziejów stosunków Rzeczypospolitej ze Stolica Apostolska i Ukraina, red. M.R. Drozdowski, W. Walczak, K. Wiszowata-Walczak, Białystok 2012, s. 573-585.

Kęder W., Stolica Apostolska wobec Rzeczypospolitej w okresie konfederacji barskiej 1767-1773, Opole 2006.

Konopczyński W., Konfedracja barska, t. 1, Kraków 1936.

Kraushar A., Ksiązę Repnin i Polska. W pierwszym czteroleciu panowania Stanistawa Augusta (1764-1768), t. 2, Warszawa 1900.

Squicciarini D., Nunzi apostolici a Vienna, Città del Vaticano 1988.

\section{Streszczenie}

W artykule przedstawiono rosyjską ofensywę w gazetach europejskich z początku 1768 r., kiedy to Petersburg, dążąc do wymuszenia na polskim sejmie przyznania specjalnych praw dla innowierców, skierował swoje działania przeciwko nuncjaturze warszawskiej, stawiającej w obronie praw katolików opór tym działaniom. W związku z wycofaniem się carycy Katarzyny II z działań skierowanych przeciwko nuncjaturze całą akcję rozpoczętą w marcu 1768 r. szybko zakończono.

Słowa kluczowe: dyplomacja papieska, nuncjatura warszawska, gazety europejskie, nuncjusz Angelo Maria Durini 


\section{The European Press as a Tool of Russian Diplomacy in its Struggle with the Holy See During the Radom Sejm of 1767-1768 \\ Summary}

This article presents the Russian operation in European newspapers from the beginning of 1768 when St. Petersburg, seeking to force the Polish Sejm to grant special rights for religious dissidents, directed his actions against the Warsaw nunciature, which resisted these actions in defense of the rights of Catholics. Due to the withdrawal of Tsarina Catherine II from her actions against the nunciature, the whole action, which began in March 1768, was quickly terminated.

Keywords: Papal diplomacy, Warsaw nunciature, European newspapers, Gazeta Cologne, Gazeta Leydeyska, nuncio Angelo Maria Durini, Jan Evangelista Stefanini auditor of the Warsaw nunciature 